\title{
Phylogenetic Relationships between Four Salix L. Species Based on DArT Markers
}

\author{
Jerzy A. Przyborowski ${ }^{1}$, Paweł Sulima ${ }^{1, *}$, Anna Kuszewska ${ }^{1}$, Dariusz Załuski ${ }^{1}$ and Andrzej Kilian ${ }^{2}$ \\ 1 Departament of Plant Breeding and Seed Production, University of Warmia and Mazury, \\ Plac Łódzki 3, Olsztyn 10-724, Poland; E-Mails: jerzy.przyborowski@uwm.edu.pl (J.A.P.); \\ anna.kuszewska@uwm.edu.pl (A.K.); dariusz.zaluski@uwm.edu.pl (D.Z.) \\ 2 Diversity Arrays Technology Pty Limited, 1 Wilf Crane Crescent, Yarralumla ACT 2600, \\ Australia; E-Mail: a.kilian@diversityarrays.com \\ * Author to whom correspondence should be addressed; E-Mail: pawel.sulima@uwm.edu.pl; \\ Tel.: +48-89-523-4844; Fax: +48-89-523-4880.
}

Received: 21 October 2013; in revised form: 28 November 2013 / Accepted: 2 December 2013 / Published: 11 December 2013

\begin{abstract}
The objectives of this study were to evaluate the usefulness of DArT markers in genotypic identification of willow species and describe genetic relationships between four willow species: Salix viminalis, $S$. purpurea, $S$. alba and $S$. triandra. The experimental plant material comprised 53 willow genotypes of these four species, which are popularly grown in Poland. DArT markers seem to identify Salix species with a high degree of accuracy. As a result, the examined species were divided into four distinct groups which corresponded to the four analyzed species. In our study, we observed that $S$. triandra was very different genetically from the other species, including $S$. alba which is generally classified into the same subgenus of Salix. The above corroborates the findings of other authors who relied on molecular methods to reveal that the classification of $S$. triandra to the subgenus Salix was erroneous. The Principal Coordinate Analysis (PCoA) and the neighbor-joining dendrogram also confirmed the clear division of the studied willow genotypes into four clusters corresponding to individual species. This confirmed the usefulness of DArT markers in taxonomic analyses and identification of willow species.
\end{abstract}

Keywords: phylogenetic relationships; genetic diversity; species identity; diversity arrays technology; DArT; Salix; willow 


\section{Introduction}

According to Argus [1], the genus Salix L. (willow) comprises around 450 species and an undefined number of natural and artificial hybrids. Willows are characterized by a high degree of genetic diversity. The genus inhabits mostly cold and moderate climate zones of the northern hemisphere [2,3]. Selected species are grown for a wide range of practical applications, including in the power engineering sector, pharmaceutical industry, wicker production and environmental management [4-8]. In recent years, willow has attracted considerable interest from farmers, industrial manufacturers and scientists. This popularity gave rise to numerous research publications investigating the genus Salix L. [6-12]. New willow farms are created, and willow biomass has a variety of industrial applications. Salix purpurea and $S$. alba plants are used in pharmaceutical applications [5,7], whereas $S$. viminalis and $S$. triandra belong to species used for energy production $[6,8,9]$.

Since the Linnaean era [13], the attempts to systematize the genus Salix have been fraught with many problems, and the willow's taxonomic status remains a subject of debate among botanists [1,2,13-17]. Argus [1] distinguished five basic subgenera of the genus Salix: Protitea, Salix, Longifoliae, Chamaetia, Vetrix (Figure 1). The main problem in systematic classification stems from willow's ability to produce a wide variety of interspecies hybrids. The willow is also characterized by high seasonal, ecological and environmental variation. Sub-genera and species of Salix L. are generally identified based on morphological traits, including the color, shape and hairiness of leaves and shoots, as well as the structure, shape and color of inflorescences [2,3]. The fact that the willow is a dioecious genus with different flowering and leaf formation rates further complicates the matter. In many species, the pigmentation of leaves and shoots changes during growth and under the influence of environmental factors, such as temperature and day length. For this reason, the issue remains open despite many years of research attempting to systematize the taxon's classification status $[1,2,16,17]$.

Figure 1. Systematic of genus Salix L. divided into five subgenera [1].

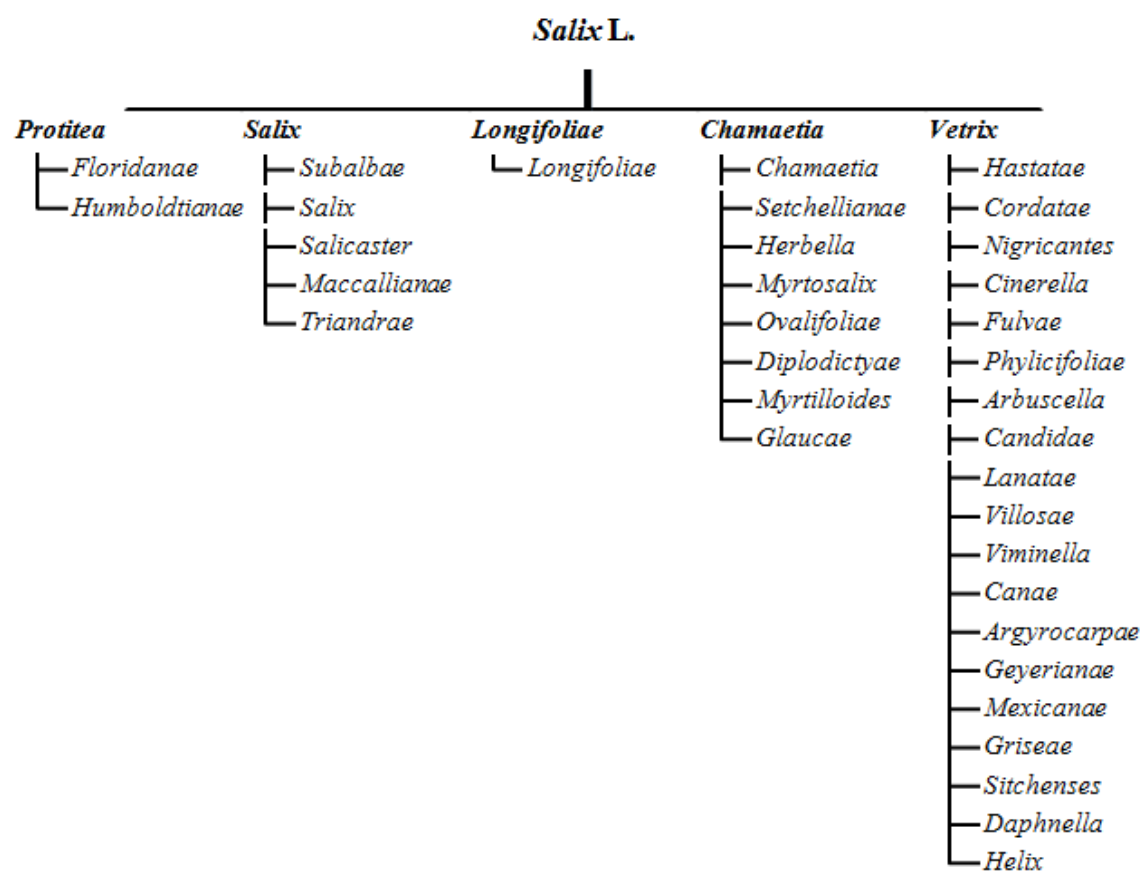


Molecular techniques play an increasingly important role in taxonomic studies and analyses of genetic diversity of living organisms [18-21]. Techniques that rely on DNA analysis are a useful analytical tool in every developmental stage of living organisms. Those methods are not affected by environmental factors; they are characterized by high repeatability and ease of use. Species identification with molecular markers is particularly recommended when morphological analyses produce ambiguous or problematic results [18,20]. The above applies to members of the genus Salix. Molecular methods for species identification rely these days on analyses of DNA polymorphism [19-21]. Taxonomic classification is based on similarities or differences between the genetic material of the studied forms. The determination of species-specific sequences of DNA supports correct identification. Molecular methods support the identification of organisms at developmental stages that are difficult to determine with the use of conventional methods, most of which rely on evaluations of morphological and anatomical traits [20,22,23].

Various marker systems capable of generating several (Random Amplification of Polymorphic DNA-RAPD, Inter-Simple Sequence Repeat-ISSR) to thousands of markers (Single Nucleotide Polymorphism-SNP) have been developed in recent decades [23-26]. Researchers have a preference for low-cost systems that effectively identify a large number of molecular markers within a relatively short period of time. Diversity Arrays Technology (DArT) [27] is such a system. By relying on DNA microarrays, this technique supports simultaneous analyses of thousands of loci distributed across the entire genome without prior knowledge of its sequence [28-31]. To date, DArT markers have supported the genomic analysis of over 70 organisms (http://www.diversityarrays.com, [32]). DArT is used mainly for genome mapping and sequencing, QTL (Quantitative Trait Loci) identification, marker-assisted selection, genetic diversity analyses and studies of varietal and species diversity of organisms. The DArT technique is not affected by the genome size or the ploidy level of the analyzed organisms [33].

The objectives of this study were: (1) to develop DArT for willow; (2) to evaluate the usefulness of DArT markers in genotyping of willow species; and (3) to describe genetic relationships between four willow species which are popularly grown in Poland, and in other European and world regions.

\section{Results and Discussion}

The analysis of 53 willow genotypes (Table 1) on DArT discovery array resulted in identification of 1362 markers with 95\% average call rate and average technical reproducibility derived from full technical replication of all samples used in analysis at 99.9\%. An analysis of basic genetic differentiation parameters (values of $\Phi_{S T}$ and Nei's genetic distance index- $D_{S}$ ) (Table 2) confirmed the results of other studies which suggest that the genus Salix is characterized by considerable genetic diversity $[17,34,35]$. In our study, the average value of $\Phi_{S T}$ reached 0.754 for only four analyzed species, which indicates a high diversity among them (Table 3 ).

$S$. triandra was highly genetically different from the other species, including $S$. alba which is generally classified into the same subgenus of Salix $[1,2,16]$. The above corroborates the findings of other authors who relied on molecular methods $[17,34]$ to reveal that the classification of $S$ triandra to the subgenus Salix was erroneous. Chen et al. [17] have argued that the section Triandrae should be excluded from the subgenus Salix. The above claim was formulated based on the results of molecular 
analyses, differences in bark exfoliation on old stems (which is more similar to Chosenia) [2], smaller amounts of nuclear DNA [36] and the fungal species Melampsora amygdalinae which causes willow rust and colonizes only $S$. triandra [37].

Table 1. List of 53 Salix genotypes used in this study, their name in collection and symbol in Principal Coordinate Analysis.

\begin{tabular}{|c|c|c|c|c|c|c|c|c|}
\hline Species & $\begin{array}{l}\text { Name in } \\
\text { Collection }\end{array}$ & $\begin{array}{c}\text { Symbol } \\
\text { PCoA }\end{array}$ & Species & $\begin{array}{c}\text { Name in } \\
\text { Collection }\end{array}$ & $\begin{array}{c}\text { Symbol } \\
\text { PCoA }\end{array}$ & Species & $\begin{array}{l}\text { Name in } \\
\text { Collection }\end{array}$ & $\begin{array}{c}\text { Symbol } \\
\text { PCoA }\end{array}$ \\
\hline S. alba & UWM075 & A1 & S. purpurea & UWM165 & P10 & S. viminalis & UWM070 & V6 \\
\hline S. alba & UWM200 & A2 & S. purpurea & UWM164 & P11 & S. viminalis & UWM073 & V7 \\
\hline S. alba & UWM180 & A3 & S. purpurea & UWM029 & P12 & S. viminalis & UWM072 & V8 \\
\hline S. alba & UWM177 & A4 & S. purpurea & UWM142 & P13 & S. viminalis & UWM071 & V9 \\
\hline S. alba & UWM176 & A5 & S. triandra & UWM187 & $\mathrm{T} 1$ & S. viminalis & UWM067 & V10 \\
\hline S. alba & UWM175 & A6 & S. triandra & UWM198 & $\mathrm{T} 2$ & S. viminalis & UWM065 & V11 \\
\hline S. alba & UWM074 & A7 & S. triandra & UWM056 & $\mathrm{T} 3$ & S. viminalis & UWM063 & V12 \\
\hline S. alba & UWM094 & A8 & S. triandra & UWM055 & $\mathrm{T} 4$ & S. viminalis & UWM034 & V13 \\
\hline S. alba & UWM093 & A9 & S. triandra & UWM197 & T5 & S. viminalis & UWM196 & V14 \\
\hline S. purpurea & UWM199 & $\mathrm{P} 1$ & S. triandra & UWM191 & T6 & S. viminalis & UWM160 & V15 \\
\hline S. purpurea & UWM174 & $\mathrm{P} 2$ & S. triandra & UWM190 & $\mathrm{T} 7$ & S. viminalis & UWM158 & V16 \\
\hline S. purpurea & UWM173 & P3 & S. triandra & UWM189 & $\mathrm{T} 8$ & S. viminalis & UWM157 & V17 \\
\hline S. purpurea & UWM172 & P4 & S. triandra & UWM188 & T9 & S. viminalis & UWM130 & V18 \\
\hline S. purpurea & UWM170 & P5 & S. viminalis & UWM079 & V1 & S. viminalis & UWM144 & V19 \\
\hline S. purpurea & UWM169 & P6 & S. viminalis & UWM078 & V2 & S. viminalis & UWM133 & V20 \\
\hline S. purpurea & UWM168 & P7 & S. viminalis & UWM077 & V3 & S. viminalis & UWM132 & V21 \\
\hline S. purpurea & UWM167 & P8 & S. viminalis & UWM145 & V4 & S. viminalis & UWM131 & V22 \\
\hline S. purpurea & UWM166 & P9 & S. viminalis & UWM154 & V5 & & & \\
\hline
\end{tabular}

Table 2. Matrix based on mean pairwise $\Phi_{S T}$ distance (below diagonal) and matrix on Nei's distance $\left(D_{S}\right)$ (above diagonal) between four species of Salix.

\begin{tabular}{ccccc}
\hline & S. alba & S. purpurea & S. triandra & S. viminalis \\
\hline S. alba & - & 0.320 & 0.687 & 0.371 \\
S. purpurea & 0.687 & - & 0.802 & 0.264 \\
S. triandra & 0.782 & 0.828 & - & 0.808 \\
S. viminalis & 0.707 & 0.665 & 0.822 & - \\
\hline
\end{tabular}

Table 3. Analysis of molecular variance (AMOVA) based on 1362 DArT markers for 53 individuals in four species of Salix L. $(p<0.01)$.

\begin{tabular}{ccccccc}
\hline $\begin{array}{c}\text { Source of } \\
\text { Variation }\end{array}$ & d.f. & $\begin{array}{c}\text { Sum of } \\
\text { Squares }\end{array}$ & $\begin{array}{c}\text { Mean } \\
\text { Squares }\end{array}$ & $\begin{array}{c}\text { Estimated } \\
\text { Variation }\end{array}$ & $\begin{array}{c}\text { Total } \\
\text { Variance }\end{array}$ & $\begin{array}{c}\boldsymbol{\Phi}_{\boldsymbol{S T}} \\
(\boldsymbol{p}<\mathbf{0 . 0 1})\end{array}$ \\
\hline Among Species & 3 & 8715.160 & 2905.053 & 225.787 & $75 \%$ & \\
Within Species & 49 & 3600.991 & 73.490 & 73.490 & $25 \%$ & 0.754 \\
Total & 52 & $12,316.151$ & & 299.276 & $100 \%$ & \\
\hline
\end{tabular}


In the group of the analyzed species, the lowest genetic distance was observed between $S$. purpurea and $S$. viminalis (Table 2). It should be noted, however, that their genetic differentiation parameters $\left(\Phi_{S T}=0.665 ; D_{S}=0.264\right)$ were indicative of considerable differences. DArT markers seem to identify Salix species with a high degree of accuracy. Despite the presence of close phylogenetic relationships between $S$. purpurea and $S$. viminalis and the classification of both species to the subgenus Vetrix [1,2,16], the observed genetic differences between those species support the correct identification of the analyzed willow genotypes.

An analysis of genetic variation within the examined willow species revealed a low level of diversity (Table 4). The results of the analysis of molecular variance (AMOVA) confirmed the above observation. Only $25 \%$ of molecular variation was noted within species, whereas $75 \%$ was observed between the studied species (Table 3). The highest genetic variation within species was reported in $S$. viminalis $\left(I=0.126 ; H_{e}=0.084\right)$, and the lowest in $S$. triandra $(I=0.071 ; H \mathrm{e}=0.047)$.

Table 4. Genetic diversity parameters within each of the studied species of Salix.

\begin{tabular}{cccccccc}
\hline Species & $\boldsymbol{N}$ & $\boldsymbol{N a}$ & $\boldsymbol{N e}$ & $\boldsymbol{I}$ & $\boldsymbol{H e}$ & $\boldsymbol{u H e}$ & $\boldsymbol{P r} \boldsymbol{B}$ \\
\hline S. alba & 9 & 0.866 & 1.095 & 0.079 & 0.053 & 0.057 & 77 \\
S. purpurea & 13 & 0.829 & 1.114 & 0.097 & 0.065 & 0.068 & 37 \\
S. triandra & 9 & 0.647 & 1.081 & 0.071 & 0.047 & 0.050 & 135 \\
S. viminalis & 22 & 0.984 & 1.145 & 0.126 & 0.084 & 0.086 & 83 \\
Mean & 12.860 & 0.831 & 1.109 & 0.093 & 0.062 & 0.065 & 83 \\
\hline
\end{tabular}

$N$ : sample size; Na: number of different alleles; Ne: mean number of effective alleles; I: Shannon's diversity index; He: expected Nei's heterozygosity; $u H \mathrm{e}$ : unbiased expected Nei's heterozygosity; PrB: number of private bands per species.

Figure 2. Principal coordinate analysis (PCoA) of 53 individual Salix plants based on DArT data.

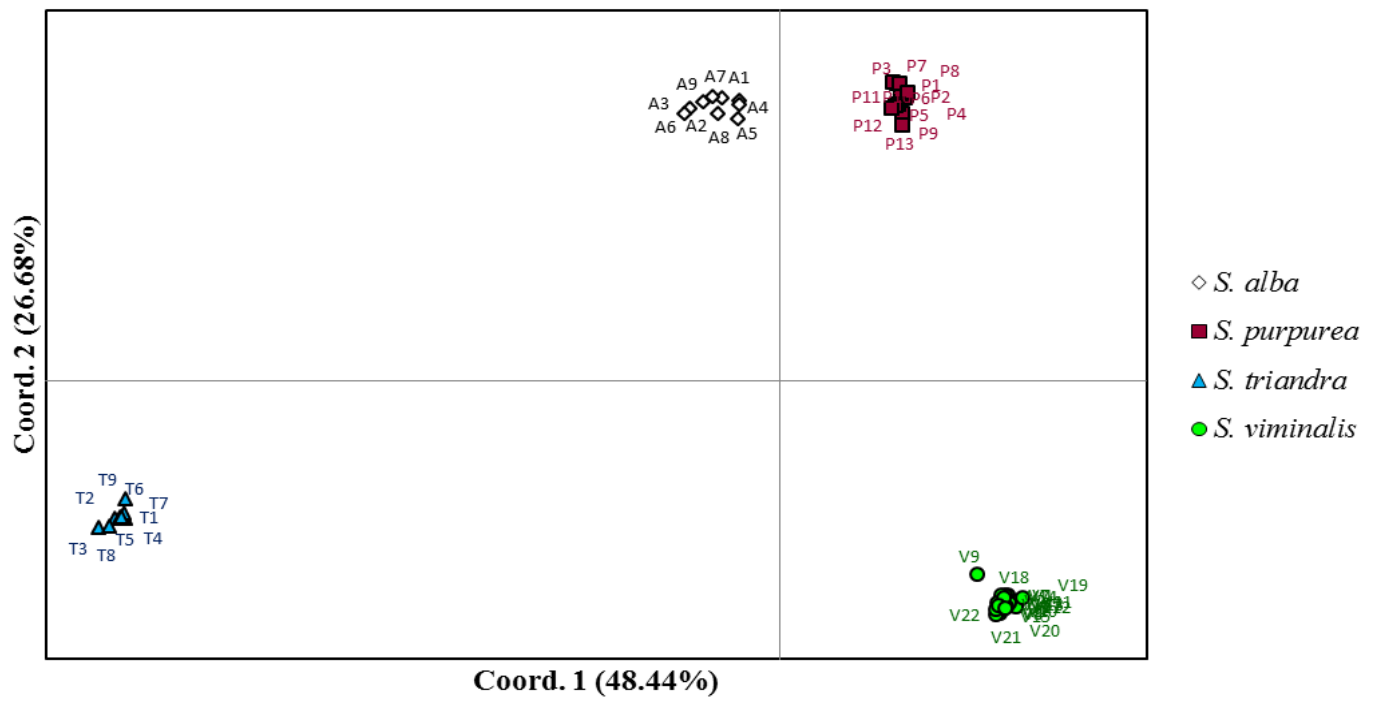

Species-specific markers are valuable tools in analyses of species' identities. In this study, a high number of private markers were determined for every examined species (Table 4). The highest number of species-specific markers was reported for S. triandra (135), which further asserts its distinctness from the remaining species. In practice, the effectiveness of species-specific markers increases with the 
number of analyzed genotypes originating from the largest possible group of species. The usefulness of species-specific DArT markers in analyses of other plant genera and species was confirmed by other authors [38,39].

Figure 3. Neighbor-joining dendrogram showing the relationships among the all studied genotypes of Salix based on Nei's genetic distances.

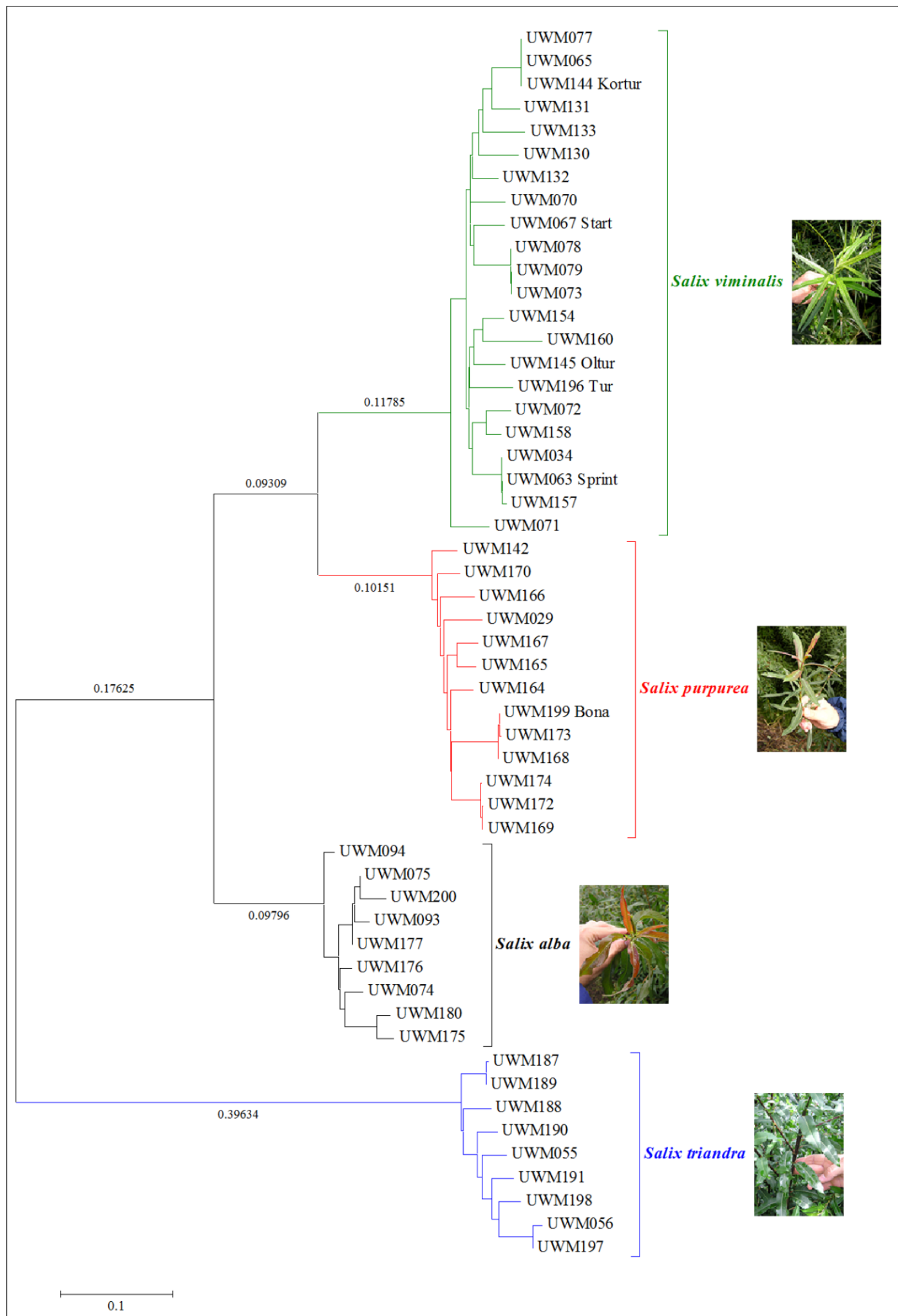


In our study, the Principal Coordinate Analysis (PCoA) explained 75.12\% of genetic variation between willow species (Figure 2). As a result, the examined species were divided into four distinct groups of clusters which corresponded to the four analyzed species. Only the UWM071 genotype (identified as V9 in PCoA) appeared to be clearly separate from the $S$. viminalis group, which raises doubts about its taxonomic classification in the $S$. viminalis species. An evaluation of the morphological traits of the UWM071 genotype validated those doubts, and the genotype was ultimately classified as an interspecies hybrid of $S$. viminalis $\times S$. dasyclados. The fact that the $S$. purpurea group was found in the proximity of $S$. alba, but it was significantly distant from the more related taxonomic group of $S$. viminalis, was also surprising. Despite the above, the structure of the neighbor-joining dendrogram points to greater genetic similarity between $S$. purpurea and S. viminalis (Figure 3). The dendrogram also confirmed the clear division of the studied willow genotypes into four clusters corresponding to individual species. A considerable genetic distance was also noted between $S$. triandra and the remaining species, which supports our previous observations concerning this taxon's classification rank.

To date, molecular methods have been rarely used to analyze the species identity or taxonomic relationships within the genus Salix Leskinen and Alström-Rapaport [40] used ribosomal (5.8 S) ITS 1 and ITS 2 in a study investigating the phylogenesis of Salicaceae and phylogenetic relationships with Flacourtiaceae. Azuma, et al. [41] tested phylogenetic relationships of the genus Salix with the involvement of the chloroplast $r b c L$ gene. Chen et al. [17] also relied on chloroplast markers ( $r b c L$ gene, $a t p B-r b c L$ and $t r n D-T$ spacers) to propose significant changes in the classification of the genus Salix Trybush et al. [34] confirmed the usefulness of amplified fragment length polymorphisms (AFLP) in genetic diversity analyses of a broad spectrum of willow species as well as in taxonomic studies.

\section{Materials and Methods}

\subsection{Plant Material}

The experimental material comprised 53 willow individuals from the collection of the Department of Plant Breeding and Seed Production at the University of Warmia and Mazury in Olsztyn, Poland. The analyzed genotypes were preliminarily classified into four species. $S$. alba was represented by nine individuals, S. purpurea-by 13, S. triandra-by 9 and S. viminalis-by 22 individuals (Table 1). The species were identified based on a botanical key [42].

\subsection{DNA Isolation and DArT Protocol}

The DNA of different genotypes was isolated from young leaf tissue according to the DNA Extraction Protocol for DArT (http://www.diversityarrays.com/sites/default/files/pub/DArT_DNA_ isolation.pdf) [43].

\subsection{Preparation of Genomic Representations}

Genomic representations were generated by cutting $100 \mathrm{ng}$ of a DNA samples from each used in study genotype of Salix with 2 units of both PstI and MspI restriction enzymes. A PstI adapter (5'-CAC GAT GGA TCC AGT GCA-3' annealed with 5'-CTG GAT CCA TCG TGC A-3') was ligated 
with T4 DNA ligase (NEB, Beverly, MA, USA). A $1 \mu \mathrm{L}$ aliquot of the ligation product was used as a template in $50 \mu \mathrm{L}$ amplification reactions with DArT-PstI primer (5'-GAT GGA TCC AGT GCA G-3') and a PCR program applicable to all plant species tested so far: $94{ }^{\circ} \mathrm{C}$ for $1 \mathrm{~min}$, followed by 30 cycles of $94{ }^{\circ} \mathrm{C}$ for $20 \mathrm{~s}, 58^{\circ} \mathrm{C}$ for $40 \mathrm{~s}, 72{ }^{\circ} \mathrm{C}$ for $1 \mathrm{~min}$, and $72{ }^{\circ} \mathrm{C}$ for $7 \mathrm{~min}$.

\subsection{Preparation of DArT Libraries and Arrays}

Libraries of genomic representations were prepared essentially as by Jaccoud et al. [27]. Individual clones were grown in 384-well plates containing LB medium supplemented with $100 \mathrm{mg} / \mathrm{L}$ ampicillin and a "freezing mix" $\left(1 \times \mathrm{LB}\right.$ medium containing $4.4 \%$ glycerol, $8.21 \mathrm{~g} / \mathrm{L} \mathrm{K}_{2} \mathrm{HPO}_{4}, 1.80 \mathrm{~g} / \mathrm{L} \mathrm{KH}_{2} \mathrm{PO}_{4}$, $0.50 \mathrm{~g} / \mathrm{L} \mathrm{Na}$-citrate, $0.10 \mathrm{~g} / \mathrm{L} \mathrm{MgSO}_{4} \times 7 \mathrm{H}_{2} \mathrm{O}, 0.90 \mathrm{~g} / \mathrm{L}\left(\mathrm{NH}_{4}\right)_{2} \mathrm{SO}_{4}, 100 \mathrm{mg} / \mathrm{L}$ Ampicilin and $100 \mathrm{mg} / \mathrm{L}$ kanamycin). Small aliquots of the cultures were used as templates to amplify inserts according to Kilian et al. [33]. The quality of the amplifications was verified by gel electrophoresis, dried, dissolved in spotting buffer [33] and spotted in duplicate onto SuperChip poly-L-lysine slides (Erie Microarray, Portsmouth, NH, USA) by using aMicroGrid II arrayer (Biorobotics, Cambridge, UK). After printing, slides were heated to $80^{\circ} \mathrm{C}$ for $2 \mathrm{~h}$, incubated in hot water $\left(95^{\circ} \mathrm{C}\right)$ for 2 min, and dried by centrifugation.

\subsection{Fingerprinting of DNA Samples}

Genomic representations of individual Salix genotypes were generated by using the same complexity reduction method as the one used to generate the libraries. Genomic representations were concentrated 10-fold by precipitation with 1 vol of isopropanol, denatured and labeled with $1 \mathrm{mM}$ Cy3-dUTP or $1 \mathrm{mM}$ Cy5-dUTP and the exo-Klenow fragment of Escherichia coli DNA polymerase I (NEB) according to Kilian et al. [33]. Labeled representations, called targets, were added to $50 \mu \mathrm{L}$ of a 50:5:1 mixture of ExpressHyb buffer (Clontech, Palo Alto, CA, USA), $10 \mathrm{~g} / \mathrm{L}$ herring sperm DNA, and the FAM-labeled polylinker fragment of the plasmid used for library preparation as a reference [27]. The samples were denatured and hybridized to microarrays overnight at $65{ }^{\circ} \mathrm{C}$. Slides were washed according to Jaccoud et al. [27] and scanned on an Affymetrix 428 (Santa Clara, CA, USA) or Tecan LS300 (Grödig, Salzburg, Austria) confocal laser scanner.

\subsection{Image Analysis and Polymorphism Scoring}

DArTsoft (Diversity Arrays Technology, Yarralumla, Australia) [44], a software package developed by DArT PL (http://www.diversityarrays.com/software.html) [44], was used to both identify and score the markers that were polymorphic within such an experiment. DArTsoft automatically localized the spots in all scanner image pairs generated in an experiment, rejected those with weak reference signals identified using the package of DArTsoft software: microarray image analysis, and computed and normalized background-subtracted relative hybridization intensities (calculated as $\log$ [cy3target/cy5reference]). The software then compared the relative intensity values for each individual genotype across slides by using a combination of fuzzy C-means clustering at a "fuzziness" level of 1.5 [27] and ANOVA: If two clusters (alleles) could be distinguished and the between-cluster variance in relative intensity was at least $80 \%$ of the total variance, the clone was called polymorphic 
and scored as 0 or 1 . A clone was incorporated into the $0 / 1$ scoring table of a particular experiment if it was scored with a probability of $p>0.95$ in at least $90 \%$ of the slides (scoring probabilities were estimated by the clustering algorithm). Individual calls with $p<0.95$ were scored as missing. Slides with $<90 \%$ of the identified polymorphic markers scored at $p>0.95$ were rejected (typically less than 5\%).

\subsection{Marker Scoring and Statistical Analysis}

The results of polymorphic scoring are presented in an Excel binary file where "1" denotes the presence, and " 0 " the absence of a marker in genomic representation of a sample. The results were processed in the following applications: GenAlEx 6.5 [45,46], Aflpsurvey 1.0 [47], Popgene 1.32 [48] and MEGA 5.1 [49]. The basic genetic differentiation parameters were presented for the studied species. The number of observed alleles $(\mathrm{Na})$, the number of effective alleles $(\mathrm{Ne})$ [50], the mean Nei's gene diversity index $(\mathrm{He})$, the unbiased gene diversity index $(u H \mathrm{e})$ [51], the Shannon diversity index $(I)[52]$ and the number of private bands per species $(\operatorname{Pr} B)$ were determined for the examined species. To assess the extent of genetic differentiation among species, were calculated pairwise distances $\left(\Phi_{S T}\right.$ values) according to Weir and Cockerham [53] and Nei's genetic distances $\left(D_{S}\right)$ according to Nei [54]. An analysis of molecular variance (AMOVA) [55] was performed to determine the percentage share of components of genetic variation. Genetic variation of the studied willow genotypes was visualized by Principal Coordinate Analysis (PCoA) based on binary genetic distance (Euclidean distance). A neighbor-joining dendrogram [56] was developed based on Nei's genetic distance matrix data [54].

\section{Conclusions}

Our findings contribute to scientific efforts aiming to standardize the taxonomic classification of the genus Salix, and they provide valuable knowledge about genetic relationships within and between the species of $S$. alba, $S$. purpurea, $S$. triandra and $S$. viminalis. The present study has confirmed the usefulness of DArT markers in taxonomic analyses and identification of willow species. Of great importance is the fact that willow species chosen for the research have major economic value in many countries. The biomass of $S$. viminalis and $S$. triandra is used on a large scale in the production of heat energy. As far as the pharmaceutical industry is concerned, of great significance is the bark of S. purpurea and $S$. alba that is used in the production of analgesic, antipyretic, anti-inflammatory and anti-rheumatic drugs. The obtained results will facilitate the assessment of genetic variation in Salix breeding materials. Salix purpurea and $S$. alba plants are used for the production of hybrids with an increased salicylic glycoside content in the bark (pharmaceutical applications) [57], whereas $S$. viminalis and $S$. triandra plants are included in breeding programs aiming to produce varieties with a high biomass energy potential [58].

\section{Acknowledgments}

This work has been financed by the strategic program of the National (Polish) Centre for Research and Development (NCBiR): “Advanced Technologies for Energy Generation. Task 4: Elaboration of 
Integrated Technologies for Production of Fuels and Energy from Biomass, Agricultural Waste and other Waste Materials".

\section{Conflicts of Interest}

The authors declare no conflict of interest.

\section{References}

1. Argus, G.W. Salix (Salicaceae) distribution maps and a synopsis of their classification in North America, north of Mexico. Harv. Pap. Bot. 2007, 12, 335-368.

2. Skvortsov, A.K. Willows of the USSR; Nauka: Moscow, Russia, 1968.

3. Hörandl, E.; Florineth, F.; Hadacek, F. Weiden in Österreich und angrenzenden Gebieten, Arbeitsbereich Ingenieurbiologie u. Landschaftsbau, Univ. Bodenkultur Wien: Wien, Austria, 2002.

4. Kuzovkina, Y.A.; Quigley, M.F. Willows beyond wetlands: Uses of Salix L. species for environmental projects. Water Air Soil Pollut. 2005, 162, 183-204.

5. Sulima, P.; Przyborowski, J.A.; Wiwart, M. Willow bark-herbal raw material harvested from plants cultivated on arable lands. Herba Polonica 2006, 52, 18-25.

6. Smart, L.B.; Cameron, K.D. Genetic Improvement of Willow (Salix spp.) as a Dedicated Bioenergy Crop. In: Genetic Improvement of Bioenergy Crops; Springer: New York, NY, USA, 2008, pp. 377-396.

7. Förster, N.; Ulrichs, C.; Zander, M.; Kätzel, R. Factors influencing the variability of antioxidative phenolic glycosides in Salix species. J. Agricul. Food Chem. 2010, 58, 8205-8210.

8. Stolarski, M.J.; Szczukowski, S.; Tworkowski, J.; Wróblewska, H.; Krzyżaniak, M. Short rotation willow coppice biomass as an industrial and energy feedstock. Industrial Crops Prod. 2011, 33, 217-223.

9. Stolarski, M.J.; Szczukowski, S.; Tworkowski, J.; Krzyżaniak, M. Cost of heat energy generation from willow biomass. Renew. Energy 2013, 59, 100-104.

10. Serapiglia, M.J.; Cameron, K.D.; Stipanovic, A.J.; Abrahamson, L.P.; Volk, T.A.; Smart, L.B. Yield and woody biomass traits of novel shrub willow hybrids at two contrasting sites. Bioenerg. Res. 2012, 6, 1-14.

11. Rosso, L.; Facciotto, G.; Bergante, S.; Vietto, L.; Nervo, G. Selection and testing of Populus alba and Salix spp. as bioenergy feedstock: Preliminary results. Appl. Energy 2012, 102, 87-92.

12. Trybush, S.O.; Jahodová, Š.; Č́žzová, L.; Karp, A.; Hanley, S.J. High levels of genetic diversity in Salix viminalis of the Czech Republic as revealed by microsatellite markers. Bioenerg. Res. 2012, 5, 1-9.

13. Linnaeus, C. Species Plantarum; Laurentius Salvius: Stockholm, Sweden, 1753.

14. Du Mortier, B.C. Verhandeling over het Geschlacht der Wilgen (Salix) en de Natuurlijke Familie der Amentaceae; bij Joh. van der Hey en zoon: Amsterdam, The Netherlands, 1825.

15. Nakai, T. Chosenia, a new genus of Salicaceae. Botanical Mag. (Tokyo) 1920, 34, 66-69. 
16. Fang, Z.; Zhao, S.; Skvortsov, A. Salicaceae. In Flora of China, Wu, Z., Raven, P., Eds.; Science Press and Missouri Botanical Garden Press: Beijing, China and St. Louis, MO, USA, 1999; Volume 4, pp. 139-274.

17. Chen, J.; Sun, H.; Wen, J.; Yang, Y. Molecular phylogeny of Salix L.(Salicaceae) inferred from three chloroplast datasets and its systematic implications. Taxon 2010, 59, 29-37.

18. Bachmann, K. Evolution and the genetic analysis of populations: 1950-2000. Taxon 2001, 50, $7-45$.

19. Ford, C.S.; Ayres, K.L.; Toomey, N.; Haider, N.; Stahl, J.V.; Kelly, L.J.; Wikstrom, N.; Hollingsworth, P.M.; Duff, R.J.; Hoot, S.B.; et al. Selection of candidate coding DNA barcoding regions for use on land plants. Botanical J. Linn. Soc. 2009, 159, 1-11.

20. Stuessy, T.F. Plant Taxonomy: The Systematic Evaluation of Comparative Data; Columbia University Press: New York, NY, USA, 2009.

21. Hollingsworth, P.M.; Graham, S.W.; Little, D.P. Choosing and using a plant DNA barcode. PLoS One 2011, 6, e19254.

22. Zanke, C.; Hemleben, V. A new Solanum satellite DNA containing species-specific sequences which can be used for identification of genome parts in somatic hybrids of potato. Plant Sci. 1997, 126, 185-191.

23. King, R.A.; Harris, S.L.; Karp, A.; Barker, J.H. Characterisation and inheritance of nuclear microsatellite loci for use in population studies of the allotetraploid Salix alba-Salix fragilis complex. Tree Genet. Gen. 2010, 6, 247-258.

24. Rafalski, J.A. Novel genetic mapping tools in plants: SNPs and LD-based approaches. Plant Sci. 2002, 162, 329-333.

25. Semagn, K.; Bjørnstad, Å.; Ndjiondjop, M. An overview of molecular marker methods for plants. Afr. J. Biotechnol. 2010, 5, 2540-2568.

26. Sá, O.; Pereira, J.A.; Baptista, P. Optimization of DNA extraction for RAPD and ISSR analysis of Arbutus unedo L. Leaves. Int. J. Mol. Sci. 2011, 12, 4156-4164.

27. Jaccoud, D.; Peng, K.; Feinstein, D.; Kilian, A. Diversity arrays: A solid state technology for sequence information independent genotyping. Nucl. Acids Res. 2001, 29, e25.

28. Kilian, A.; Huttner, E.; Wenzl, P.; Jaccoud, D.; Carling, J.; Caig, V.; Evers, M.; Heller-Uszynska, K.; Cayla, C.; Patarapuwadol, S. The Fast and the Cheap: SNP and DArT-based Whole Genome Profiling for Crop Improvement. Proceedings of International Congress "In the Wake of the Double Helix: From the Green Revolution to the Gene Revolution”, Bologna, Italy, 27-31 May 2003; Tuberosa, R., Phillips, R.L., Gale, M., Eds.; Avenue Media: Bologna, Italy, 2005; pp. 443-461.

29. Steane, D.A.; Nicolle, D.; Sansaloni, C.P.; Petroli, C.D.; Carling, J.; Kilian, A.; Myburg, A.A.; Grattapaglia, D.; Vaillancourt, R.E. Population genetic analysis and phylogeny reconstruction in Eucalyptus (Myrtaceae) using high-throughput, genome-wide genotyping. Mol. Phylogenet. Evolut. 2011, 59, 206-224.

30. Hudson, C.J.; Kullan, A.R.; Freeman, J.S.; Faria, D.A.; Grattapaglia, D.; Kilian, A.; Myburg, A.A.; Potts, B.M.; Vaillancourt, R.E. High synteny and colinearity among Eucalyptus genomes revealed by high-density comparative genetic mapping. Tree Genet. Genomes 2012, 8, 339-352. 
31. Belaj, A.; del Carmen Dominguez-García, M.; Atienza, S.G.; Martín Urdíroz, N.; De la Rosa, R.; Satovic, Z.; Martín, A.; Kilian, A.; Trujillo, I.; Valpuesta, V. Developing a core collection of olive (Olea europaea L.) based on molecular markers (DArTs, SSRs, SNPs) and agronomic traits. Tree Genet. Genomes 2012, 8, 365-378.

32. Diversity Arrays Technology Homepage. Available online: http://www.diversityarrays.com (accessed on 20 October 2013).

33. Kilian, A.; Wenzl, P.; Huttner, E.; Carling, J.; Xia, L.; Blois, H.; Caig, V.; Heller-Uszynska, K.; Jaccoud, D.; Hopper, C.; et al. Diversity Arrays Technology: A Generic Genome Profiling Technology on Open Platforms. In Data Production and Analysis in Population Genomics; Pompanon, F., Bonin, A., Eds.; Humana Press: New York, NY, USA, 2012; Volume 888, pp. 67-89.

34. Trybush, S.; Jahodová, Š.; Macalpine, W.; Karp, A. A genetic study of a Salix germplasm resource reveals new insights into relationships among subgenera, sections and species. Bioenergy Res. 2008, 1, 67-79.

35. Nybom, H. Comparison of different nuclear DNA markers for estimating intraspecific genetic diversity in plants. Mol. Ecol. 2004, 13, 1143-1155.

36. Thibault, J. Nuclear DNA amount in pure species and hybrid willows (Salix): A flow cytometric investigation. Can. J. Bot. 1998, 76, 157-165.

37. Pei, M.; Hunter, T.; Royle, D. Host-pathogen relationship between Salix and Melampsora sheds light on the parentage of some biomass willows. New Phytol. 2002, 141, 155-160.

38. Hearnden, P.; Eckermann, P.J.; McMichael, G.; Hayden, M.; Eglinton, J.K.; Chalmers, K.J. A genetic map of 1000 SSR and DArT markers in a wide barley cross. TAG Theor.Appl. Genet. 2007, 115, 383-391.

39. Kopecký, D.; Bartoš, J.; Lukaszewski, A.; Baird, J.; Černoch, V.; Kölliker, R.; Rognli, O.; Blois, H.; Caig, V.; Lübberstedt, T. Development and mapping of DArT markers within the Festuca-Lolium complex. BMC Genomics 2009, 10, 473.

40. Leskinen, E.; Alström-Rapaport, C. Molecular phylogeny of Salicaceae and closely related Flacourtiaceae: Evidence from 5.8 S, ITS 1 and ITS 2 of the rDNA. Plant Syst. Evolut. 1999, 215, 209-227.

41. Azuma, T.; Kajita, T.; Yokoyama, J.; Ohashi, H. Phylogenetic relationships of Salix (Salicaceae) based on rbcL sequence data. Am. J. Bot. 2000, 87, 67-75.

42. Neumann, A. Die Mitteleuropäischen Salix-Arten; Mitt Forstlichen Bundes-versuchsanstalt: Wien, Austria, 1981.

43. Plant DNA Extraction Protocol for DArT. Available online: http://www.diversityarrays. com/sites/default/files/pub/DArT_DNA_isolation.pdf (accessed on 20 October 2013).

44. DArTsoft; Available online: http://www.diversityarrays.com/software.html (accessed on 20 October 2013).

45. Peakall, R.; Smouse, P.E. GenAlEx 6: Genetic analysis in Excel. Population genetic software for teaching and research. Mol. Ecol. Notes 2006, 6, 288-295.

46. Peakall, R.; Smouse, P.E. GenAlEx 6.5: Genetic analysis in Excel. Population genetic software for teaching and research-an update. Bioinformatics 2012, 28, 2537-2539. 
47. Vekemans, X.; Beauwens, T.; Lemaire, M.; Roldán-Ruiz, I. Data from amplified fragment length polymorphism (AFLP) markers show indication of size homoplasy and of a relationship between degree of homoplasy and fragment size. Mol. Ecol. 2002, 11, 139-151.

48. Yeh, F.C.; Yang, R.C.; Boyle, T.B.J.; Ye, Z.H.; Mao, J.X. POPGENE, the User-Friendly Shareware for Population Genetic Analysis. In Molecular Biology and Biotechnology Centre; University of Alberta: Edmonton, AB, Canada, 1997.

49. Tamura, K.; Peterson, D.; Peterson, N.; Stecher, G.; Nei, M.; Kumar, S. MEGA5: Molecular evolutionary genetics analysis using maximum likelihoevolutionary distance and maximum parsimony methods. Mol. Biol. Evolut. 2011, 28, 2731-2739.

50. Hartl, D.L.; Clark, A.G. Principles of Population Genetics; Sinauer: Sunderland, UK, 2007.

51. Nei, M. In (1973) analysis of gene diversity in subdivided populations. Proc. National Acad. Sci. USA 1973, 70, 3321-3323.

52. Shannon, C.E.; Weaver, W. The Mathematical Theory of Communication; University of Illinois Press: Urbana, IL, USA, 1949.

53. Weir, B.S.; Cockerham, C.C. Estimating F-statistics for the analysis of population structure. Evolution 1984, 38, 1358-1370.

54. Nei, M. Genetic distance between populations. Am. Nat. 1972, 106, 283-292.

55. Excoffier, L.; Smouse, P.E.; Quattro, J.M. Analysis of molecular variance inferred from metric distances among DNA haplotypes: Application to human mitochondrial DNA restriction data. Genetics 1992, 131, 479-491.

56. Saitou, N., Nei, M. The neighbor-joining method: A new method for reconstructing phylogenetic trees. Mol. Biol. Evolut. 1987, 4, 406-425.

57. Sulima, P.; Przyborowski, J.A.; Załuski, D. RAPD markers reveal genetic diversity in Salix purpurea L. Crop Sci. 2009, 49, 857-863.

58. Przyborowski, J.P.; Sulima, P. The analysis of genetic diversity of Salix viminalis genotypes as a potential source of biomass by RAPD markers. Industrial Crops Product. 2010, 31, 395-400.

(C) 2013 by the authors; licensee MDPI, Basel, Switzerland. This article is an open access article distributed under the terms and conditions of the Creative Commons Attribution license (http://creativecommons.org/licenses/by/3.0/). 